\title{
Sprouting Sustainable Industrial and Technological Workforce through Technical Vocational Education and Training in South- South, Nigeria
}

\author{
Jane Itohan Oviawe ${ }^{*}$, Pauline E. Ehirheme ${ }^{2}$ \\ 1Department of Vocational and Technical Education, Ambrose Alli University, Edo State, Nigeria \\ ${ }^{2}$ Department of Office Technology and Management, Yaba College of Technology, Lagos State, Nigeria \\ *Corresponding author, e-mail: janeoviawe@aauekpoma.edu.ng
}

\begin{abstract}
The call for continuous creation of industrial and technological workforce cannot be overlooked, in view of the fact that it will boost the sustainable industrial and technological development of any nation. A vital programme that can bring into being requisite workforce for sustainable industrial and technological development is Technical Vocational Education and Training (TVET). To this end, this study investigated the strategies for sprouting sustainable industrial and technological workforce through TVET in Nigeria using the descriptive survey research design. The study was guided with two research questions and two hypotheses. The sample was made up of 300 respondents comprising of 154 TVET Lecturers from Universities and 146 TVET industry-based workers in South-South Geopolitical Zone of Nigeria, who were selected using simple random and convenience sampling techniques respectively. The instrument used for data collection was a 69item questionnaire which was validated by three experts. The reliability of the instrument was determined using Cronbach Alpha and a reliability coefficient of .86 was obtained. Mean and standard deviations statistics were used to answer the research questions, whereas t-test statistic was used to test the null hypotheses at .05 level of significance. The findings of this study revealed that TVET programmes had some policy-related challenges; and TVET institutions-workplace collaboration is a possible strategy for sprouting sustainable industrial and technological workforce in Nigeria. Thus, among others, it was recommended that firm TVET policy document be set-up by government and all stakeholders to appropriately synchronize TVET programmes towards sprouting sustainable industrial and technological workforce in Nigeria.
\end{abstract}

Keywords: Policies, Strategies, Sustainable Development, Technical Vocational Education and Training, Workforce.

\section{INTRODUCTION}

Education is globally acclaimed to be the means of industrial and technological development. It is a means of acquiring useful skills that will enable an individual live a meaningful life in the dynamic society. It is a means of liberation from ignorance, poverty, joblessness/unemployment and a channel for change and national development. Buttressing this, Danmole (cited in Oviawe, 2019) posited that education is not only a channel for transformation and national development, but a collective process and the standard for the achieving of appropriate knowledge, skills and attitude for subsistence in a world that is ever, continuously dynamic. It is a truism that no scientifically and technologically development can take place in any nation without functional and wellorganized educational programmes. This type of functional educational programme is Technical Vocational Education and Training (TVET).

TVET is intended to prepare its recipients with the right skills and values required to be employable in the world of work. Technical Vocational Education and Training (TVET) is universally known for its responsibility in grooming people for changing aspects commitment in careers of operational worth and efficient basis of competent workforce (Oviawe, 2018). Federal Republic of Nigeria (FRN) (2013), stressed that TVET is an all- 
embracing characteristics denoted to those facets of the educational process including in addition to general education, the study of technologies and related sciences and the acquisition of practical skills, attitudes, understanding and knowledge connecting to occupations in diverse areas of economic life. The United Nations Educational Scientific and Cultural Organization (UNESCO) and the International Labour Organization (ILO) advice of 2000 on TVET for the 21st century classify TVET as: (1) an integral part of general education; (2) a process of preparing for occupational fields and effective contribution in the world of work; (3) a facet of lifelong learning and a training for responsible citizenship; (4) a means for encouraging environmentally sound sustainable advancement; (5) technique of lessening hardship (Oviawe, Uwameiye, \& Uddin, 2017).

Also, UNESCO (2012) stated that TVET embraces the education and training geared towards the acquisition of practical skills, knowledge and understanding necessary for employment in particular imparting, trade or group of occupations or trades. It is habits and related knowledge required by workers to society's need for workers. Musa \& Okorieocha (2012) asserted that TVET equips individuals with lifelong skills, to learn and work as productive citizens universally; hence the prerequisite for the work force development of a country. This implies that TVET is all about the development of useful skills in a particular area and stresses the development of occupational skills required for the workplace. Therefore, the determination of any country is in acknowledging TVET as a workplace preparatory instrument for sprouting sustainable industrial and technological workforce.

TVET sprouting is undertaken to benefit the individual/recipient, the workplace and the society. TVET institutions are expected to produce competent and skilled workforce for the industries. TVET is aimed at production of qualitative technological workforce concerning a country's collective resources of skilled, competent and enterprising artisans, craftsmen, technicians and technologists who will be capable of developing new and innovative ways of addressing technical issues in the society. Abdullahi (cited in Abdulrahaman, 2013) stated that development in TVET is closely associated to innovative patterns and happenings around the globe which is a direct function of technological changes. In the perspective of this study, sprouting TVET workforce is the training that expose an individual to the demands of the industrial and technological advancement in Nigeria.

The industrial and technological advancement of any nation is determined by the products from the industries, commerce and agriculture, of which TVET is mandated to sprout the workforce required in the workplace. This is in line with earlier assertion of Musa \& Okorieocha (2012) that technological advancement of a nation is indivisible from TVET. To this end, Yusuff \& Soyemi (2012) stated that TVET skills are fundamental to economic advancement as they are required for industry productivity and profitability in addition to personal prosperity. Without skilled and competent workforce produced by TVET institutions for the world of work, industrial and technological advancement of any country will practically pulverize to a standstill. Describing the attributes of TVET, Ozoemena (2013) posited that a nation cannot be self-reliant without fully engaging its human (workforce) and material resources in the production of necessity products. TVET stands closest to the cross roads of classroom and the real world, and hence is able to combine technical knowledge and business acumen, creativity and innovations for effective job performance (Egbiri \& Chukwuedo, 2013). To this end, Ejiofor \& Nwakile (2016) stated that this is necessary because there is a gap between what is obtainable in the classroom and that which is needed in the workplace. So investing on TVET means training of persons who will fill the current and future skill needs gap for unforeseen challenges. TVET no doubt has the capacity of providing and equipping its recipients with relevant skills required for sprouting

Oviawe, J. I., \& Ehirheme, P. E. (2019). Sprouting Sustainable Industrial and Technological Workforce through Technical Vocational Education and Training in South-South, Nigeria. Journal of Vocational Education Studies, 2(2), 113-126. D0I: https://doi.org/10.12928/joves.v2i2.1192. 
sustainable industrial and technological workforce but has been faced with several constraints and bottlenecks. To remove all constraints and bottlenecks that will affect the realization of the goals and objectives of TVET, initiatives and framework can be put in place by government, the workplace/industries or other relevant stakeholders for implementation.

Implementation is the act of carrying out tasks, in order to give practical effect for ensuring actual achievement by concrete measures (Webster, 2010). In the context of this study, implementation is the execution of all the TVET initiatives and policies towards sprouting sustainable industrial and technological workforce in Nigeria. Oliatan (2003) explained implementation of programme objectives as techniques, process or method of expanding the content of what is planned to the target audience which help to achieve success. To ensure implementation of TVET programmes for sprouting sustainable industrial and technological workforce in Nigeria, appropriate initiatives and policy must be put in place to remove all constraints and bottlenecks that will affects its realization of goals and objectives.

Initiative is a plan or process that has been stated for the purpose of achieving a particular aim or to resolve a difficulty (Auta, 2009). In the highlight of this study, initiative is a group of meaningful statements that could serve as a guideline towards sprouting sustainable industrial and technological workforce through TVET. Such initiatives could be developed into policies that will serve as a guide in addressing challenges of TVET for sustainable industrial and technological workforce. A policy is a mission statement formulated to guide actions or specific end. Policy expresses the expected goals of a given plan. It is an establishment of objectives or plan of that which is to done in a given circumstance that has been decided officially by a consortium of persons, organizations, or government. It is a precise course or process of action selected from among options and in light of given requirements to guide and ascertain present and future decisions. Mcclean (cited in Okeke, 2007) stated that policy is a statement that is intended to be a binding guide on the actions of those designated by the statement. FRN (2013) in her national policy on education put forward the guidelines, objectives, standards, structures, strategies, and management for achieving the national education (TVET inclusive) objectives in Nigeria. In the highlight of this study, policy denotes initiatives that are clearly stated and directed to serve as a binding force and guide from the government, world of work and all TVET stakeholders to elicit proper actions and attitudes towards sprouting sustainable industrial and technological workforce in Nigeria. This could be achieved through TVET-workplace collaboration.

TVET has been acknowledged by many nations universally for helping to advance a professionally skilled workforce crucial to economic and technological advancement (Oviawe, 2018). Grunewald (cited in Oviawe, 2018) postulated that the economic development essential for a nation's advancement and fighting poverty is too difficult without private sector contribution. Grunewald opined that private enterprises play a vital role in generating jobs and income for society and individuals. According to Abubakar (2010), reversing and successive advancement of TVET focused at advancement of technology and scientific innovations cannot be attained by government alone but it has to be in partnership with the workplace that has the technical expertise, vocational competencies and financial proficiency. The workplace collaboration may include technology backing in terms of training and retraining of staff and students, financial assistance and expertise through contribution in curriculum improvement, networks, and access to contemporary production paraphernalia, tools, machines and technical knowhow.

Oviawe, J. I., \& Ehirheme, P. E. (2019). Sprouting Sustainable Industrial and Technological Workforce through Technical Vocational Education and Training in South-South, Nigeria. Journal of Vocational Education Studies, 2(2), 113-126. D0I: https://doi.org/10.12928/joves.v2i2.1192. 
The Organization for Economic Cooperation and Development (OECD) (2013) expressed that the workplace can organize workplace orientation through internships, apprenticeship, collaborative education and continuing education and training (CET) schemes. OECD added that in internship, students go to work in enterprises in their expected career with little or no compensation for a period ranging from a few weeks to several months. Practicums give real work experiences to those who need to investigate or acquire the appropriate knowledge and skills mandatory to enter into a specific vocation (Oviawe, 2018). Grunewald outlined the following as the main areas of partnership between TVET institutions and the workplace: (1)classifying training requirements of technical staff; (2) setting standards for the vocational and technical educators; (3) improving training programmes/syllabi for TVET institutions; (4)training and retraining of technical teachers and workshop attendants; (5) improving teaching and learning materials; (6) qualifying and supplying teachers and instructors; (7) planning and putting into practice training measure; (8) setting up and putting into practice testing and examination systems; (9)evaluating the application, significance, effectiveness and efficiency as well as effect of training measures and associated activities; and (10) economic activities. It is presumed that the partnership between TVET institutions (government) and the workplace outcome will produce skill improvement appropriate to the workplace grants, technology, technical know-how among others, while, the public sector has strong policies to guide the workplace; therefore, the blend will be enormous and great.

\section{Problem of The Study}

Even with all the roles played by TVET in job creation, high unemployment is still evident in Nigeria. The statement of the National Bureau of Statistics (NBS) for the second quarter of 2018 shows that unemployment rate is now $14.3 \%$ which equates to 27.06 million people. Soaring joblessness has led to upsurge hardship and other societal vices such as prostitution, human trafficking, arm robbery, kidnapping, drug trafficking, among others in Nigeria. Unemployment has led most graduates roaming the streets looking for what to do. Concurrently, there has been a regression in TVET registrations (Oviawe, 2017). The failure of TVET to move fast in the attainment of industrial and technological development in Nigeria despite her huge human and material resources and investment is a clear indication that there are inherent issues in both the preparation and execution of TVET policies. Researches (Ajao, 2008; Oviawe \& Uwameiye, 2019) revealed that the national policy on education and the introduction of 6-3-34 system and TVET curriculum in particular was not bad but rather it was poorly implemented. The issues of poor implementation included among others, poor definition of goals, lack of clear definition of responsibilities, over-ambitions policy goals, inappropriate organizational structure, timing factor, corruption, and political opposition/insensitivity to demands.

To launch Nigeria as a developing nation into the orbit of industrial and technological advancement in the current globalized village, her TVET policies must be properly formulated and implemented involving the workplace/industries and other relevant stakeholders. Heads of TVET institutions (technical colleges, colleges of education (technical), polytechnics and others) must be masters/professionals who understand the rudiments and practical applications of TVET policies, what TVET is, and what benefits that can come from it. For this reason, there is the need for proper policy framework and its implementations. Where non-professionals head TVET institutions and educational establishments, implementations of TVET policies usually suffer. The problem of this study therefore, is to determine TVET policy provisions, practice and implementation that could

Oviawe, J. I., \& Ehirheme, P. E. (2019). Sprouting Sustainable Industrial and Technological Workforce through Technical Vocational Education and Training in South-South, Nigeria. Journal of Vocational Education Studies, 2(2), 113-126. D0I: https://doi.org/10.12928/joves.v2i2.1192. 
be adopted as strategies towards sprouting sustainable industrial and technological workforce in Nigeria.

\section{Purpose of the Study}

The purpose of this study is to determine TVET policy provisions, practice and implementation that could be adopted as strategies for sprouting sustainable industrial and technological workforce in South-South Nigeria. Purposely, this study sought to determine the: (1) TVET policies related issues for sprouting sustainable industrial and technological workforce in South-South Nigeria; (2) The extent of practices of TVET policies for the realization of sustainable industrial and technological workforce in South-South Nigeria; and (3) The strategies for implementations of TVET policies needed for sustainable industrial and technological workforce in South-South Nigeria.

\section{RESEARCH METHOD}

Descriptive survey research design was adopted to investigate the strategies for sprouting sustainable industrial and technological workforce through TVET in South-South Nigeria in this study. There were 300 respondents comprising of 154 TVET Lecturers from Universities and 146 TVET industry-based workers in South-South Geopolitical Zone of Nigeria made up of the population for this study. Simple random and convenience sampling techniques were used respectively.

The data collection instrument was a 69-item questionnaire which was validated by three experts. One of the experts was from Department of Vocational and Technical Education, Ambrose Alli University, Ekpoma, another from Test and Measurement Department, Delta State University, Abraka and the third was from the industry who is employer of TVET products. Cronbach Alpha was used as an instrument to determine the reliability, and obtained a reliability coefficient of .86. The questionnaire items were structured based on Likert's five-point scale of Strongly Agree (SA)-5, Agree (A)-4, Undecided (U)-3, Disagree (D)-2 and Strongly Disagree (SD)-1. Distributed and retrieved the instruments to the respondents were through the assistance of seven research assistants. The 300 copies of questionnaire were dully answered and returned and had a return rate of $100 \%$.

Mean and standard deviations statistics were used in analyzing the data collected, to answer the research questions, while t-test statistic was used tested the null hypotheses at .05 level of significance. The decision point was put at 3.00 based on the five-point scale. This implies that items with mean values of 3.00 and above were considered as agreed whereas, items with mean value below 3.00 were considered as disagreed. The standard deviations (SD) of the items were also analyzed. Any item with SD value of 1.96 or below indicated that the respondents were near to the mean and to each other in their responses. On the other hand, any item with SD value above 1.96 showed that the respondents were far from the mean and each other in their responses. For the null hypotheses, they were retained if the calculated t-test value was greater than the table value of 1.96 at .05 level of significance or otherwise rejected.

\section{RESULTS AND DISCUSSION}

Our first research question was: What are the TVET policies related issues for sprouting sustainable industrial and technological workforce in South-South Nigeria? This question leads to the Hypothesis 1, "There is no significant difference in the perception of TVET Lecturers and Industry based supervisors on the TVET policies related issues for

Oviawe, J. I., \& Ehirheme, P. E. (2019). Sprouting Sustainable Industrial and Technological Workforce through Technical Vocational Education and Training in South-South, Nigeria. Journal of Vocational Education Studies, 2(2), 113-126. DOI: https://doi.org/10.12928/joves.v2i2.1192. 
sprouting sustainable industrial and technological workforce in Nigeria". To test this hypothesis, we collected the data as presented in Table 1.

Table 1. Mean rating on the TVET policies related Issues for sprouting sustainable industrial and technological workforce

\begin{tabular}{|c|c|c|c|c|c|c|c|c|c|c|}
\hline \multirow{2}{*}{ S/No } & \multirow{2}{*}{ Items } & \multirow{2}{*}{$\mathbf{G X}$} & \multirow{2}{*}{ SD } & \multirow{2}{*}{$\mathbf{X}_{1}$} & \multirow{2}{*}{$\mathrm{SD}_{1}$} & \multirow{2}{*}{$\mathbf{X}_{2}$} & \multirow{2}{*}{$\mathbf{S D}_{2}$} & \multirow{2}{*}{$\begin{array}{c}\text { P- } \\
\text { Value }\end{array}$} & \multicolumn{2}{|c|}{ Remarks } \\
\hline & & & & & & & & & RQ & $\mathrm{Ho}_{0}$ \\
\hline 1 & $\begin{array}{l}\text { Broadly identify the measures and } \\
\text { requisites in the TVET document. }\end{array}$ & 3.51 & .99 & 3.14 & .94 & 3.88 & 1.09 & .24 & A & NS \\
\hline 2 & $\begin{array}{l}\text { Experts in TVET are recognized by } \\
\text { others as having the right } \\
\text { responsibility to formulate } \\
\text { policies. }\end{array}$ & 3.23 & .93 & 3.22 & .97 & 3.24 & .89 & .94 & A & NS \\
\hline 3 & $\begin{array}{l}\text { Policies formation model of } \\
\text { human resource improvement }\end{array}$ & & & & & & & & & \\
\hline & $\begin{array}{l}\text { from TVET will facilitate in } \\
\text { sustainable industrial and } \\
\text { technological workforce. }\end{array}$ & 3.64 & .75 & 3.51 & .82 & 3.76 & .61 & .12 & A & NS \\
\hline 4 & $\begin{array}{l}\text { Workplace policies allied to TVET } \\
\text { for valuable workforce growth. }\end{array}$ & 3.40 & .97 & 3.17 & 1.07 & 3.64 & .70 & .22 & A & NS \\
\hline 5 & $\begin{array}{l}\text { Detach TVET policy linking to } \\
\text { workplace that will steer TVET. }\end{array}$ & 3.36 & .98 & 3.70 & .95 & 3.03 & 1.03 & .21 & A & NS \\
\hline 6 & $\begin{array}{l}\text { Re-examine the TVET curricula to } \\
\text { meet the workplace requirement } \\
\text { for the creation of demand driven } \\
\text { TVET workforce. }\end{array}$ & 3.85 & 1.08 & 3.73 & 1.06 & 3.97 & 1.11 & .30 & A & NS \\
\hline 7 & $\begin{array}{l}\text { TVET Policies should incorporate } \\
\text { TVET-Workplace collaboration to } \\
\text { fortify the tie between public and } \\
\text { private sectors. }\end{array}$ & 3.80 & 1.05 & 3.85 & .96 & 3.78 & 1.21 & .71 & A & NS \\
\hline 8 & $\begin{array}{l}\text { TVET provide workforce in the } \\
\text { applied sciences, technology and } \\
\text { business specifically at craft, sub- } \\
\text { craft, technical levels. }\end{array}$ & 3.40 & .87 & 3.59 & .79 & 3.21 & .95 & .35 & A & NS \\
\hline 9 & $\begin{array}{l}\text { TVET policies entails interaction } \\
\text { with a variety of external interest } \\
\text { groups. }\end{array}$ & 3.50 & .80 & 3.47 & .82 & 3.53 & .79 & .75 & A & NS \\
\hline 10 & $\begin{array}{l}\text { Policy making team should consist } \\
\text { of balanced figures of TVET } \\
\text { experts from educational } \\
\text { institutions and the workplace. }\end{array}$ & 3.57 & .76 & 3.60 & .79 & 3.53 & .71 & .70 & A & NS \\
\hline 11 & $\begin{array}{l}\text { The current TVET innovations and } \\
\text { Policies are adequate for creating } \\
\text { sustainable industrial and } \\
\text { technological workforce. }\end{array}$ & 3.34 & .91 & 3.29 & .91 & 3.38 & .92 & .63 & A & NS \\
\hline 12 & $\begin{array}{l}\text { Measures for deciding the likely } \\
\text { quantity of graduates required in } \\
\text { the workplace from TVET } \\
\text { institutions be specified } \\
\text { adequately in the policy. }\end{array}$ & 3.10 & .96 & 3.08 & 1.00 & 3.12 & .91 & .88 & A & NS \\
\hline 13 & $\begin{array}{l}\text { Decisions about TVET policies are } \\
\text { enforceable by TVET experts, } \\
\text { stipulated workplace. }\end{array}$ & 2.86 & .98 & 2.70 & .95 & 3.03 & 1.03 & .21 & $\mathrm{D}$ & NS \\
\hline 14 & $\begin{array}{l}\text { TVET policy specify the decisive } \\
\text { factor for conducting researches } \\
\text { towards meeting the industrial } \\
\text { and technological needs and the }\end{array}$ & 3.74 & .61 & 3.74 & .58 & 3.74 & .67 & .94 & A & NS \\
\hline
\end{tabular}

Oviawe, J. I., \& Ehirheme, P. E. (2019). Sprouting Sustainable Industrial and Technological Workforce through Technical Vocational Education and Training in South-South, Nigeria. Journal of Vocational Education Studies, 2(2), 113-126. D0I: https://doi.org/10.12928/joves.v2i2.1192. 


\begin{tabular}{|c|c|c|c|c|c|c|c|c|c|c|}
\hline \multirow{3}{*}{ S/No } & \multirow{2}{*}{ Items } & \multirow{3}{*}{$\mathbf{G X}$} & \multirow{3}{*}{ SD } & \multirow{3}{*}{$\mathbf{X}_{1}$} & \multirow{3}{*}{$\mathrm{SD}_{1}$} & \multirow{3}{*}{$\mathbf{X}_{2}$} & \multirow{3}{*}{$\mathbf{S D}_{2}$} & \multirow{3}{*}{$\begin{array}{c}\text { P- } \\
\text { Value }\end{array}$} & \multicolumn{2}{|c|}{ Remarks } \\
\hline & & & & & & & & & RQ & $\mathrm{Ho}_{\mathrm{O}}$ \\
\hline & $\begin{array}{lll}\text { quantity of } & \text { needed } & \text { TVET } \\
\text { workforce. }\end{array}$ & & & & & & & & & \\
\hline 15 & $\begin{array}{l}\text { Reasonable quantity of } \\
\text { workplaces be involved in the } \\
\text { making, implementing and } \\
\text { assessing of TVET policies. }\end{array}$ & 3.62 & .61 & 3.62 & .64 & 3.62 & .55 & .94 & A & NS \\
\hline 16 & $\begin{array}{l}\text { TVET policies involve exchange of } \\
\text { information, resources and } \\
\text { discussion bargain between and } \\
\text { within the workplace. }\end{array}$ & 2.81 & 1.08 & 2.73 & 1.06 & 2.97 & 1.11 & .30 & D & NS \\
\hline 17 & $\begin{array}{l}\text { TVET policies clearly specify the } \\
\text { roles of the workplace and TVET } \\
\text { educational institutions. }\end{array}$ & 3.41 & .80 & 3.61 & .67 & 3.20 & .95 & .20 & A & NS \\
\hline 18 & $\begin{array}{l}\text { TVET policies take place } \\
\text { principally Within workplace } \\
\text { structures. }\end{array}$ & 2.82 & .95 & 2.80 & .96 & 2.88 & .94 & .68 & $\mathrm{D}$ & NS \\
\hline 19 & $\begin{array}{l}\text { Create the measures for assessing } \\
\text { TVET policy implementation } \\
\text { process. }\end{array}$ & 3.54 & .75 & 3.49 & .82 & 3.59 & .61 & .55 & A & NS \\
\hline 20 & $\begin{array}{l}\text { Identify the measures for } \\
\text { incorporating the actions of TVET } \\
\text { institutions and workplace needs. }\end{array}$ & 3.20 & .77 & 3.19 & .80 & 3.21 & .73 & .91 & A & NS \\
\hline 21 & $\begin{array}{l}\text { TVET policies are directed at the } \\
\text { future they are constantly } \\
\text { concerned with probabilities and } \\
\text { economic conditions but also } \\
\text { about low values, norms and tastes } \\
\text { many changes. }\end{array}$ & 2.82 & .95 & 2.80 & .96 & 2.88 & .94 & .68 & $\mathrm{D}$ & NS \\
\hline 22 & $\begin{array}{l}\text { Create room for collaboration } \\
\text { among the TVET institutions and } \\
\text { the workplace in the policy. }\end{array}$ & 3.44 & .74 & 3.44 & .75 & 3.44 & .74 & .99 & A & NS \\
\hline 23 & $\begin{array}{l}\text { TVET policy specify ways of } \\
\text { improving students/staff welfare } \\
\text { and development beside } \\
\text { industrial/technological dangers. }\end{array}$ & 3.63 & .57 & 3.58 & .62 & 3.74 & .45 & .19 & A & NS \\
\hline 24 & $\begin{array}{l}\text { TVET provide training and input } \\
\text { the necessary skills to its } \\
\text { recipients' as required by the } \\
\text { workplace. }\end{array}$ & 2.81 & 1.05 & 2.85 & .96 & 2.76 & 1.21 & .71 & $\mathrm{D}$ & NS \\
\hline Note: & & & & & & & & & & \\
\hline GX & : Grand Mean, & & & & & & & & & \\
\hline $\mathrm{X}_{1}$ & : Mean of Lecturers, & & & & & & & & & \\
\hline $\mathrm{X}_{2}$ & : Mean of Industry-based Supervisors, & & & & & & & & & \\
\hline $\mathrm{SD}_{1}$ & : Standard Deviation of Lecturers, & & & & & & & & & \\
\hline $\mathrm{SD}_{2}$ & : Standard deviation of Industry-based & Super & isors, & & & & & & & \\
\hline A & : Agreed, & & & & & & & & & \\
\hline $\mathrm{D}$ & : Disagreed, & & & & & & & & & \\
\hline$S$ & : Significant, & & & & & & & & & \\
\hline NS & : Not Significant & & & & & & & & & \\
\hline
\end{tabular}

In response to research question 1, Table 1 shows that the respondents agreed that 19 out of the 24 items with mean rating ranging from 3.10 to 3.85 as all functional policy related issues in South-South Nigeria. The respondents disagreed with items 13, 16, 18, 21 and 24 with mean rating ranging from 2.81 to 2.86 . The standard deviations of all the 24 items were below 1.96 indicating that the respondents were near to the mean and to each other in their responses. These items are policy related issues but not practiced hence, they

Oviawe, J. I., \& Ehirheme, P. E. (2019). Sprouting Sustainable Industrial and Technological Workforce through Technical Vocational Education and Training in South-South, Nigeria. Journal of Vocational Education Studies, 2(2), 113-126. D0I: https://doi.org/10.12928/joves.v2i2.1192. 
are not functional policy in South-South Nigeria. This implies that there is need to build up TVET policies for sprouting sustainable industrial and technological workforce in Nigeria.

Also, data presented in Table 1 indicated that the calculated t-test values of all the items were below the table value of 1.96 at .05 level of significance. Therefore, the null hypothesis of no significant difference was retained for all the items.

Our second research question was: "What are the practices of TVET policy for the realization of sustainable industrial and technological workforce in Nigeria? It leads to Hypothesis 2, "There is no significant difference in the perception of TVET Lecturers and Industry based Supervisors on the practices of TVET policy for the realization of sustainable industrial and technological workforce in South-South Nigeria". To test this hypothesis, we collected the data as presented in Table 2 .

Table 2. Mean Rating on TVET Policy Practices for Sprouting Sustainable Industrial and Technological Workforce

\begin{tabular}{|c|c|c|c|c|c|c|c|c|c|c|}
\hline \multirow{2}{*}{ S/No } & \multirow{2}{*}{ Items } & \multirow{2}{*}{ GX } & \multirow{2}{*}{ SD } & \multirow{2}{*}{$X_{1}$} & \multirow{2}{*}{$\mathbf{S D}_{1}$} & \multirow{2}{*}{$\mathbf{X}_{2}$} & \multirow{2}{*}{$\mathbf{S D}_{2}$} & \multirow{2}{*}{$\begin{array}{c}\text { P- } \\
\text { Value }\end{array}$} & \multicolumn{2}{|c|}{ Remarks } \\
\hline & & & & & & & & & & $\mathrm{H}_{\mathbf{O}}$ \\
\hline 1 & $\begin{array}{l}\text { Features for curricular activities } \\
\text { for TVET are structured. }\end{array}$ & 3.88 & 1.17 & 3.79 & 1.11 & 3.97 & 1.22 & .79 & A & NS \\
\hline 2 & $\begin{array}{l}\text { Effective participation of students } \\
\text { in practical work. }\end{array}$ & 2.53 & .96 & 2.50 & .94 & 2.56 & .97 & .32 & D & NS \\
\hline 3 & $\begin{array}{l}\text { Sufficient personnel to guide the } \\
\text { Students in practical works }\end{array}$ & 2.04 & 1.05 & 2.02 & 1.05 & 2.06 & 1.05 & .20 & $\mathrm{D}$ & NS \\
\hline 4 & $\begin{array}{l}\text { TVET operates a production unit } \\
\text { for on-the-job training of students } \\
\text { and for commercial activities to } \\
\text { sustain TVET institutions } \\
\text { operations. }\end{array}$ & 2.70 & 1.10 & 2.75 & 1.00 & 2.65 & 1.19 & .45 & D & NS \\
\hline 5 & $\begin{array}{l}\text { Practical works are usually } \\
\text { evaluated by Teachers. }\end{array}$ & 2.88 & 1.10 & 2.78 & 1.00 & 2.65 & 1.19 & .45 & D & NS \\
\hline 6 & $\begin{array}{l}\text { More emphasis on theory rather } \\
\text { than practical. }\end{array}$ & 3.29 & .75 & 3.28 & .83 & 3.30 & .67 & .15 & A & NS \\
\hline 7 & Gender bias in practical works. & 3.05 & .71 & 3.00 & .85 & 3.10 & .56 & .71 & A & NS \\
\hline 8 & $\begin{array}{l}\text { job creators upon the completion } \\
\text { of their programmes. }\end{array}$ & 3.43 & .82 & 3.36 & .83 & 3.50 & .80 & .29 & A & NS \\
\hline 9 & $\begin{array}{l}\text { Lukewarm attitude of the } \\
\text { Government towards TVET }\end{array}$ & 3.44 & .67 & 3.32 & .79 & 3.56 & .55 & .67 & A & NS \\
\hline 10 & $\begin{array}{l}\text { Inadequate finance to carry out } \\
\text { practical. }\end{array}$ & 3.07 & .73 & 2.96 & .78 & 3.18 & .68 & 1.67 & A & NS \\
\hline 11 & $\begin{array}{l}\text { Poor attitude of students towards } \\
\text { practical. }\end{array}$ & 3.32 & .89 & 3.31 & .93 & 3.33 & .85 & .12 & A & NS \\
\hline 12 & $\begin{array}{l}\text { TVET students complete their } \\
\text { programmes without incubation } \\
\text { due to strike and demonstration. }\end{array}$ & 3.37 & .77 & 3.25 & .86 & 3.49 & .67 & 1.81 & A & NS \\
\hline 13 & $\begin{array}{l}\text { Teacher students ratio in TVET } \\
\text { classes is } 1: 20 \text {. }\end{array}$ & 3.26 & .84 & 3.22 & .84 & 3.30 & .83 & .84 & A & NS \\
\hline 14 & $\begin{array}{l}\text { Trainees completing TVET } \\
\text { programmes are able to pursue } \\
\text { further education. }\end{array}$ & 3.30 & .68 & 3.16 & .80 & 3.44 & .56 & 1.47 & A & NS \\
\hline 15 & $\begin{array}{l}\text { TVET institutions workshop are } \\
\text { well equipped for practical works. }\end{array}$ & 2.18 & 1.17 & 2.20 & 1.09 & 2.16 & 1.25 & .17 & D & NS \\
\hline 16 & $\begin{array}{l}\text { Products of TVET institutions are } \\
\text { able to fit into the workplace with } \\
\text { the requisites skills. }\end{array}$ & 2.91 & .81 & 2.92 & .89 & 2.90 & .72 & .14 & D & NS \\
\hline
\end{tabular}

Oviawe, J. I., \& Ehirheme, P. E. (2019). Sprouting Sustainable Industrial and Technological Workforce through Technical Vocational Education and Training in South-South, Nigeria. Journal of Vocational Education Studies, 2(2), 113-126. DOI: https://doi.org/10.12928/joves.v2i2.1192. 
In response to research question 2 , Table 2 shows that the respondents perceived items 10 out of the 16 items as agreed with mean rating ranging from 3.05 to 3.55 ; while the respondents disagreed with items six of the items with mean rating ranging from 2.04 to 2.91 . Items $1,12,13$, and 14 are in line with the national policy of education (2013) while disagreed items are incubated for reasons such as political oppositions and insensitivity. The standard deviations of all the 16 items were below 1.96 showing that the respondents were near to the mean and to each other in their responses.

Similarly, data presented in Table 2 indicated that the calculated t-test values of all the items were below the table value of 1.96 at .05 level of significance. Consequently, the null hypothesis of no significant difference was retained for all the items.

At last, our third research question was: "What are strategies for implementation of TVET policy needed for sustainable industrial and technological workforce in Nigeria? It leads to Hypothesis 3, "There is no significant difference in the perception of TVET Lecturers and Industry based Supervisors on the strategies for implementation of TVET policy for the realization of sustainable industrial and technological workforce in SouthSouth Nigeria". To test this hypothesis, we collected the data as presented in Table 3.

Table 3. Mean and Standard Deviation of Strategies for Implementation of TVET Policies Needed for Sustainable Industrial and Technological Workforce

\begin{tabular}{|c|c|c|c|c|c|c|c|c|c|c|}
\hline \multirow{2}{*}{ S/No } & \multirow{2}{*}{ Items } & \multirow{2}{*}{$\mathbf{G X}$} & \multirow{2}{*}{ SD } & \multirow{2}{*}{$\mathbf{X}_{1}$} & \multirow{2}{*}{$\mathbf{S D}_{1}$} & \multirow{2}{*}{$\mathbf{X}_{2}$} & \multirow{2}{*}{$\mathrm{SD}_{2}$} & \multirow{2}{*}{$\begin{array}{c}\text { P- } \\
\text { Value }\end{array}$} & \multicolumn{2}{|c|}{ Remarks } \\
\hline & & & & & & & & & & $\mathrm{H}_{\mathbf{O}}$ \\
\hline 1 & $\begin{array}{l}\text { TVET policy goals and objectives } \\
\text { must be clearly identified. }\end{array}$ & 3.52 & .51 & 3.52 & .51 & 3.52 & .50 & .95 & A & NS \\
\hline 2 & $\begin{array}{l}\text { TVET programmes must be } \\
\text { properly defined to realize its } \\
\text { objectives. }\end{array}$ & 3.53 & .50 & 3.52 & .50 & 3.56 & .49 & .48 & A & NS \\
\hline 3 & $\begin{array}{l}\text { TVET goals and objectives must not } \\
\text { be over ambition. }\end{array}$ & 3.54 & .50 & 3.52 & .50 & 3.58 & .50 & .34 & $\mathrm{~A}$ & NS \\
\hline 4 & $\begin{array}{l}\text { Appropriate organizational } \\
\text { structure must be employed for } \\
\text { TVET policy implementation. }\end{array}$ & 3.51 & .50 & 3.51 & .50 & 3.51 & .50 & .96 & A & NS \\
\hline 5 & $\begin{array}{l}\text { Suggestions for improvement on } \\
\text { TVET policy implementation must } \\
\text { be continuous. }\end{array}$ & 3.54 & .50 & 3.53 & .50 & 3.54 & .50 & .87 & A & NS \\
\hline 6 & $\begin{array}{l}\text { Roles of TVET experts and the } \\
\text { world of work must be properly } \\
\text { defined. }\end{array}$ & 3.58 & .50 & 3.56 & .51 & 3.62 & .49 & .35 & A & NS \\
\hline 7 & $\begin{array}{l}\text { Political oppositions must be } \\
\text { avoided during TVET policy } \\
\text { implementation. }\end{array}$ & 3.57 & .51 & 3.56 & .50 & 3.57 & .54 & .95 & A & NS \\
\hline 8 & $\begin{array}{l}\text { Compromises during TVET policy } \\
\text { implementation capable of } \\
\text { defeating policy purpose must be } \\
\text { prevented. }\end{array}$ & 3.56 & .51 & 3.55 & .51 & 3.57 & .50 & .70 & A & NS \\
\hline 9 & $\begin{array}{l}\text { Timing in the implementation of } \\
\text { TVET policies must be } \\
\text { appropriately considered. }\end{array}$ & 3.04 & .99 & 3.14 & .94 & 2.88 & 1.09 & .24 & A & NS \\
\hline 10 & $\begin{array}{l}\text { All aspects of corruption thwarting } \\
\text { TVET policy implementation must } \\
\text { be prevented. }\end{array}$ & 3.22 & .93 & 3.22 & .97 & 3.24 & .89 & .94 & A & NS \\
\hline 11 & $\begin{array}{l}\text { Workplace should be part of the } \\
\text { design and continuous review of } \\
\text { the TVET curriculum. }\end{array}$ & 3.60 & .75 & 3.51 & .82 & 3.76 & .61 & .12 & A & NS \\
\hline
\end{tabular}

Oviawe, J. I., \& Ehirheme, P. E. (2019). Sprouting Sustainable Industrial and Technological Workforce through Technical Vocational Education and Training in South-South, Nigeria. Journal of Vocational Education Studies, 2(2), 113-126. DOI: https://doi.org/10.12928/joves.v2i2.1192. 


\begin{tabular}{|c|c|c|c|c|c|c|c|c|c|c|}
\hline \multirow{2}{*}{ S/No } & \multirow{2}{*}{ Items } & \multirow{2}{*}{ GX } & \multirow{2}{*}{ SD } & \multirow{2}{*}{$\mathbf{X}_{1}$} & \multirow{2}{*}{ SD $_{1}$} & \multirow{2}{*}{$\mathbf{X}_{2}$} & \multirow{2}{*}{$\mathbf{S D}_{2}$} & \multirow{2}{*}{$\begin{array}{c}\text { P- } \\
\text { Value }\end{array}$} & \multicolumn{2}{|c|}{ Remarks } \\
\hline & & & & & & & & & RQ & $\mathbf{H o}_{0}$ \\
\hline 12 & $\begin{array}{l}\text { Define the pattern of collaboration } \\
\text { between TVET institutions and the } \\
\text { workplace. }\end{array}$ & 3.34 & .97 & 3.17 & 1.07 & 3.64 & .70 & .22 & A & NS \\
\hline 13 & Collaboration between TVET & & & & & & & & & \\
\hline & $\begin{array}{l}\text { institutions and workplace for the } \\
\text { production of the required } \\
\text { workforce. }\end{array}$ & 3.32 & .91 & 3.29 & .91 & 3.38 & .92 & .63 & A & NS \\
\hline 14 & $\begin{array}{l}\text { TVET institutions alone can pledge } \\
\text { the production of the required } \\
\text { workforce without well-designed } \\
\text { collaboration with the workplace. }\end{array}$ & 3.57 & .76 & 3.60 & .79 & 3.53 & .71 & .70 & A & NS \\
\hline 15 & $\begin{array}{l}\text { TVET institutions collaborates with } \\
\text { the work-place beyond the pattern } \\
\text { of the current Students Industrial }\end{array}$ & 3.49 & .80 & 3.47 & .82 & 3.53 & .79 & .75 & A & NS \\
\hline & 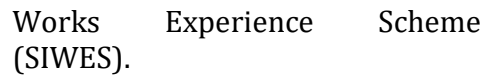 & & & & & & & & & \\
\hline 16 & Create officially authorized & & & & & & & & & \\
\hline & $\begin{array}{l}\text { measure for TVET-Workplace } \\
\text { collaboration. }\end{array}$ & 3.74 & .61 & 3.74 & .58 & 3.74 & .67 & .94 & A & NS \\
\hline 17 & $\begin{array}{l}\text { Government at all levels have to } \\
\text { direct all registered workplaces to } \\
\text { join in the partnership }\end{array}$ & 3.60 & .79 & 3.60 & .77 & 3.62 & .78 & .88 & A & NS \\
\hline 18 & $\begin{array}{l}\text { Establish the quantity of TVET } \\
\text { students and staff that will be } \\
\text { attached to a workplace. }\end{array}$ & 3.52 & .75 & 3.49 & .82 & 3.59 & .61 & .55 & A & NS \\
\hline 19 & $\begin{array}{l}\text { Determine the procedures for } \\
\text { deciding the quantity of workplace } \\
\text { staff for the collaboration. }\end{array}$ & 3.20 & .77 & 3.19 & 80 & 3.21 & .73 & .91 & A & NS \\
\hline 20 & $\begin{array}{l}\text { Set-up specific ways of enticing } \\
\text { TVE students and staff to } \\
\text { workplaces that are connected to } \\
\text { their areas of expert knowledge. }\end{array}$ & 3.62 & .61 & 3.62 & .64 & 3.61 & .55 & .94 & A & NS \\
\hline 21 & $\begin{array}{l}\text { Establish the proper stage/level(s) } \\
\text { the students have to be enticed to } \\
\text { the partnership. }\end{array}$ & 3.44 & .75 & 3.34 & .75 & 3.44 & .75 & .99 & A & NS \\
\hline 22 & $\begin{array}{l}\text { Specify the level of hands skills to } \\
\text { be attained in the partnership. }\end{array}$ & 3.63 & 57 & 3.58 & .62 & 3.74 & .45 & .19 & A & NS \\
\hline 23 & $\begin{array}{l}\text { Set-up the criteria through which } \\
\text { the workplace and academic staff } \\
\text { should collaborate }\end{array}$ & 3.11 & .92 & 3.01 & .92 & 3.30 & .91 & .16 & A & NS \\
\hline 24 & $\begin{array}{l}\text { Set-up the criteria for assessing the } \\
\text { extent of attainment during the } \\
\text { collaboration. }\end{array}$ & 3.06 & .79 & 2.98 & .82 & .3 .21 & .73 & .73 & A & NS \\
\hline
\end{tabular}

In response to research question 3 , Table 3 show that the respondents agreed with all the 24 items as strategies for implementation of TVET policies needed for sustainable industrial and technological workforce in Nigeria with Mean rating ranging from 3.043.74. The standard deviations of all the items were below 1.96 showing that the respondents were near to the mean and to each other in their responses.

In addition, data presented in Table 3 indicated that the calculated t-test values of all the items were below the table value of 1.96 at .05 level of significance. So, the null hypothesis of no significant difference was retained for all the items.

Oviawe, J. I., \& Ehirheme, P. E. (2019). Sprouting Sustainable Industrial and Technological Workforce through Technical Vocational Education and Training in South-South, Nigeria. Journal of Vocational Education Studies, 2(2), 113-126. D0I: https://doi.org/10.12928/joves.v2i2.1192. 


\section{Discussion}

The findings of this study make known that TVET policies were being formulated by TVET experts and that these policies were in line with the national policy on education. However, the respondents perceived most of the policy statements as non-functional. Majo (2010) raised these questions in finding answers to TVET policies and its experts: who were the experts? Where they experts by training? Or by positions occupied through mere political appointments? Could it be that a political appointee who was not technically qualified formulated or took part in formulating these TVET policies? These questions yearn for answers in looking at TVET policy related issues and its functionality in Nigeria.

The findings from this study as indicated that inappropriate policy implementation strategies were factors inhibiting the sprouting of TVET for sustainable industrial and technological workforce in Nigeria. Oviawe (2010) asserted that for Nigeria to realize her implementable and result oriented TVET policy, education (TVET inclusive) must remain the only instrument per excellence for national development that is capable of launching the nation to global standards and demands technologically. It is only functional education that can bring about the desired changes. A policy is not an end in itself but a means to an end. A non-functional TVET policy cannot serve as the key for opening door to the ever changing industrial and technological workforce needs of the world of work. Osinem \& Nwoji (2010) posited the incorporation of TVET into science and technology innovation (STI) policy is a factor affecting the advancement of TVET in Nigeria, thus the need for separate TVET policy towards sprouting sustainable industrial and technological workforce in Nigeria must be practiced and well implemented.

The findings of this study revealed that TVET functionality can only be achieved or felt by the world of work or society through the production of skilled and competent workforce who have gone through proper training based on well planned and implemented strategies. In line with the findings of this study, Scott (2014) posited that TVET can be fixed up for efficient industrial operational collaboration. Similarly, Nwarieji \& Osinem (2015) asserted that greater collaboration between research, TVET institutes will minimize bureaucratic process, ensure that technologies and policies are appropriate to the actual requirements of the workplace have to be emphasized to support the findings of this study. TVET brings about changes in attitude, knowledge and skills. The role of TVET involves dissemination of information, capacity building through variety of communication methods and help recipients make informed decisions. Nwarieji \& Osinem opined that there is need to legislate TVET. All nations should have a wide-range TVET policy that provide for coordination with research, input supply as well as some adaptability to reflect the changing aspects of the nature of the world of work. This policy should help maintain and conserve the industrial and technological workforce. These authors stressed that TVET policy has to be formally made mandatory through legislative enactment to give a suitable policy footing and specific directive and clear management for improving and implementing TVET programmes to support the findings of this study.

\section{CONCLUSION}

The study concludes that there are some policies related to issues and strategies that could be applied towards sprouting sustainable industrial and technological workforce in South-South Nigeria. The industrial and technological advancement of a country determines the degree of a nation's economic development. This study therefore concluded that TVET policy practice and TVET-workplace collaboration are essential to recoup the development sustainable workforce in Nigeria. It is recommended, based on the findings of this study that: (1) TVET curricular have to be re-oriented to encapsulate the demand of the ever

Oviawe, J. I., \& Ehirheme, P. E. (2019). Sprouting Sustainable Industrial and Technological Workforce through Technical Vocational Education and Training in South-South, Nigeria. Journal of Vocational Education Studies, 2(2), 113-126. DOI: https://doi.org/10.12928/joves.v2i2.1192. 
dynamic world of work; (2) TVET policies should be functional by making it responsive to existing and future demand of the world of work; (3) TVET policy structure for sustainable industrial and technological workforce should be designed by TVET experts and policy makers; (4) Government alone cannot fund TVET as it is cost intensive. Therefore, there should be partnership among TVET institutions and the workplace to enable products to attain the requisite expertise and proficiency required for sustainability.

\section{ACKNOWLEDGEMENT}

The Authors' appreciation goes to TVET lecturers from Universities and the industrybased workers in South-South Geopolitical Zone of Nigeria who responded to the instrument for data collection in the study, without whom this study would not have been possible.

\section{REFERENCES}

Abdulrahaman, W. I. (2013). Technical and vocational education: A tool for national development in Nigeria. Mediterranean Journal of Social Science, 4(8), 85-89.

Ajao, W. (2008). National policy on education (NPE) suffers poor implementation. Vanguard.

Auta, I. S. (2009). Policy initiatives for improving the administration of technical teacher training program in Nigeria. An unpublished Ph.D thesis. Nsukka: Department of Vocational Teacher Education, University of Nigeria.

Egbri, J. N. \& Chukwuedo, S. O. (2013). Re-engineering technical vocational education and training (TVET) in Nigeria through school industry collaboration for capacity building. Nigerian Vocational Association Journal, 18(1), 74-82.

Ejiofor, T. E. \& Nwakile, T. C. (2016). Revitalizing technical vocational education and training for job creation and national development through agricultural education programmes in tertiary institutions in Nigeria. Journal of Association of Vocational and Technical Educators of Nigeria (JAVTEN), 21(2), 102-110.

FRN (2013). National policy on education. Abuja: NERDC.

Moja, T. (2010). An analytical synthesis of performance and main issues in Nigerian education sector. New York: New York University

Musa, S. U., \& Okorieocha, N. (2012). Manpower development in technical and vocational education (TVE): A prerequisite for the technological development of Nigeria. Knowledge Review, 26(4), 129-135.

Nwarieji, F. E., \& Osinem, E. C. (2015). Policy-related strategies for enhancing implementation of unified agricultural extension service delivery in Imo State. International Journal of Educational Research, 14(4), 56-64.

Osinem, E. C. \& Nwoji, C. U. (2010). Students' industrial work experience in Nigeria: Concepts, principle and practices. Enugu: Cheston.

Oviawe, J. I. (2010). Technical and vocational education as a vital tool for tackling youth unemployment in Nigeria. Journal of Home Economics Educators (JOHEE), 1(1), 45-51.

Oviawe, J. I. (2017). Fostering students' enrolment in technical education programmes through career guidance and occupational awareness. Education Journal, 6(4), 125132.

Oviawe, J. I., Uwameiye, R., \& Uddin, P. S. O. (2017). Best practices in Technical Education programme for students' capacity building and sustainable development in the 21st century. Journal of Technical Education and Training (JTET), 9(2), 57-68.

Oviawe, J. I., \& Ehirheme, P. E. (2019). Sprouting Sustainable Industrial and Technological Workforce through Technical Vocational Education and Training in South-South, Nigeria. Journal of Vocational Education Studies, 2(2), 113-126. DOI: https://doi.org/10.12928/joves.v2i2.1192. 
Oviawe, J. I. (2018). Revamping technical, vocational education and training through publicprivate partnerships for skill development. Makerere Journal of Higher Education, 10(1), 1-19.

Oviawe, J. I. (2019). Effects of blended learning approach and students' academic performance in block laying and concrete works trade in technical colleges in Edo State. International Journal of Educational Benchmark, 12(1), 45-53.

Oviawe, J. I. \& Uwameiye, R. (2019). Communication skills required by technical teachers for effective implementation of basic technology curriculum in Edo State, Nigeria. ATBU Journal of Science, Technology and Education, 7(1), 276-285.

Ozoemena, S. A. (2013). Vocational and technical education: A tool for sustainable development in Nigeria. Retrieved from: http://iiste.org/Journals/index.php/JEP/article.

Webster, M. (2013). Online dictionary. Retrieved from: http://word.com/dictionary.

Scott, B. (2014). Why we cannot afford to lose CTE in schools. International Journal of Vocational and Technical Education, 6(2), 7-12.

UNESCO (2012). Technical vocational education and training for the 21st century UNESCO and ILO recommendations. Geneva: UNESCO.

Yusuff, M. A. \& Soyemi, J. (2012). Achieving sustainable economic development in Nigeria through technical and vocational education and training: The missing link. International Journal of Academic Research in Business and Social Sciences, 2(2), 7177.

Oviawe, J. I., \& Ehirheme, P. E. (2019). Sprouting Sustainable Industrial and Technological Workforce through Technical Vocational Education and Training in South-South, Nigeria. Journal of Vocational Education Studies, 2(2), 113-126. DOI: https://doi.org/10.12928/joves.v2i2.1192. 
Oviawe, J. I., \& Ehirheme, P. E. (2019). Sprouting Sustainable Industrial and Technological Workforce through Technical Vocational Education and Training in South-South, Nigeria. Journal of Vocational Education Studies, 2(2), 113-126. DOI: https://doi.org/10.12928/joves.v2i2.1192. 